\title{
The impact of lean and green practices on logistics performance: a structural equation modelling
}

\author{
Helena Sofia Rodrigues ${ }^{\mathrm{a}, \mathrm{b}}$ (D), Wellington Alves ${ }^{\mathrm{a}, \mathrm{c} *}$ (D), Ângela Silva ${ }^{\mathrm{a}, \mathrm{d}}$ (1) \\ Instituto Politécnico de Viana do Castelo, Business School, Portugal \\ bUniversidade de Aveiro, Centro de Investigação e Desenvolvimento em Matemática e Aplicações, Portugal \\ 'Universidade do Minho, Centro ALGORITMl, Portugal \\ ¿Universidade Lusíada, Centro de Investigação em Organizações, Mercados e Gestão Industrial, Portugal \\ *wellingtonbn@gmail.com
}

\begin{abstract}
Paper aims: This research has two main objectives, firstly to analyze the level of implementation of lean and green practices of a set of companies and secondly to analyze the relationship between lean and green initiatives in an industrial context.

Originality: The use of Structural Equation Modelling (SEM) allows a better analysis of the interlinkage of lean and green towards sustainable gains. The developed model offers conceptual contribution to the arena of the logistics, sustainability, lean and green.

Research methods: The methodology used in this study was carried out resorting an inquiry. Firstly, aiming to understand the level of these practices (lean and green) practices in the North of Portugal, a case study was considered. The sample taken is a convenient one, due to time and budget constraints. Secondly, in order to assess the possibility to combine lean ad and green initiatives, a statistical approach was used to develop a SEM for lean and green practices.

Main findings: The results demonstrated that the level of implementation of lean and green practices on Portuguese companies are not properly addressed and formalized. The statistical analysis also showed that lean environmental practices and green practices are positively associated. The research showed that lean and green has also a positive impact on the logistics processes of companies.

Implications for theory and practice: This research brings some contributions to both academy and companies. Firstly, a further discussion about the benefits of combining lean and green towards sustainability. Secondly, the development of a structural model for lean and green practices was presented, this model contributes to a better understanding of these practices, which can lead companies to develop strategic initiatives towards sustainability.
\end{abstract}

Keywords

Lean. Green. Structural equations modelling analysis. Logistics.

How to cite this article: Rodrigues, H. S., Alves, W., \& Silva, A. (2020). The impact of lean and green practices on logistics performance: a structural equation modelling. Production, 30, e20190072. https://doi.org/10.1590/0103-6513.20190072

Received: July 9, 2019; Accepted: Jan. 28, 2020.

\section{Introduction}

In response to the urgent need for sustainability in the industrial sector, strategies for environmental and social impacts must be considered. The sustainability strategies are traditionally based on the identification and evaluation of criteria which expose potential impacts on the three dimensions of sustainable development: social, economic and environmental (Organisation for Economic Co-operation and Development, 2010).

On account, the globalization, advance supply chains have become increasingly complex over the years. The sustainability concept has been launched in the green agenda for all industrial sector, aiming to incorporate sustainable strategies with a focus on reduction, or even elimination of the negative impacts generated by products and operational process on the environment (Bahr \& Sweeney, 2019). 
Following the agenda of sustainability, logistics has been posted as an important player in companies to the development of sustainable strategies. For instance, a work developed by Rashidi and Cullinane has investigated the sustainability of the operational logistics performance of different countries using the OCDE database as a sample (Rashidi \& Cullinane, 2019). Dey et al. (2011) have also investigated the development of initiatives towards sustainability, identifying opportunities and providing recommendations for companies regarding the implementation of sustainability strategies.

Having in mind the importance of the company's activities as well their significant environmental, social and economic impacts attributed to these activities, the need for sustainable strategies to reduce these impacts emerge as a fundamental research topic. In order to move towards greener operations, the industrial sector has been seeking alternatives to balance efficiency gains and environmental protection in their production processes.

In order to support companies to balance efficiency and environmental concerns in their operations, green and lean initiatives have increasing attention as key initiatives to address strategies which require a commitment to the environment combining efficiency.

According to Campos \& Vazquez-Brust (2016), industrial systems can be seen as subsystems and internal processes which are interconnected. Therefore, the different areas of an organization perform specific activities, however they all together act towards the achievement of the strategic goal of the organization.

Aiming to achieve a better operational result in the internal process of the organizations, associating best practices of different strategic models, Cherrafi et al. (2018), propose the adoption of combined techniques Lean and Green management to develop strategies in key areas of the organization.

Green and lean have been applied by companies separately. Yet, the combination of lean and green initiatives could have a positive impact on the organizational performance, promoting sustainable gains (Choudhary et al. 2019). However, a better understanding about the definition as well an undefined structure to manage both initiatives configure a barrier to companies' implementation.

In this context, due to the emerging importance of environmental issues within today's global arena, this research has two main objectives: firstly, to analyze the level of implementation of lean and green practices, and secondly to analyze the possibility to combine lean and green initiatives in an industrial context.

The motivation for developing this research is based on the main goal of lean and green initiatives, due to the combination of these methodologies can shed further light for companies, contributing in a systematic way to improve process and product quality as well environmental concerns.

In order to achieve the objective of this research, a review of the relevant existing literature related to lean and green practices was conducted. Then, the case of companies in the North region of Portugal was analyzed. The data were analyzed resorting to a SEM approach.

The work is organized in five main sections, as outlined next. A review of the relevant literature was conducted in Section 2. Then, a case study method was chosen in order to assess the lean and environmental management practices of the selected companies in the North of Portugal (Section 3). Statistical tools were used to analyse the answers of the companies and to study the level of engagement of these practices in the organizations. Finally, the main conclusions are carried out in Section 5.

\section{Literature review}

In order to facilitate further research on the relationship between green and lean initiatives, in the next section, this work presents a comprehensive literature review on the currents state of the art for each one of the initiatives. It is aimed at discussing critically the existing contributions of lean and green on its applications and linkage on logistics performance.

\subsection{Effect of lean initiatives on organizational performance}

The instability of the business market and the growth of companies supply chain has been improved the organization's performance to become more efficient, flexible and faster to answer first to the changes in the business environments.

Lean Manufacturing plays an important role in supporting companies to overcome environmental, social and economic impacts attributed to the production processes, which has been a major concern for the industrial sector lately (Almanei et al., 2017).

Lean Manufacturing is focused on the reduction of waste and improvement of operational efficiency using a set of different tools to get these objectives (Pearce et al., 2018). Many of these tools can be successfully used 
in isolation, which makes it much easier to get started, but on the other hand, the benefits will propagate as more tools are used, as they do support and reinforce each other.

In the literature, some studies demonstrate the influence of the application of the lean methods and tools in different performance indicators: Belekoukias et al. (2014) have analysed the impact of lean methods and tools on the operational performance of manufacturing organizations and the results indicate that Just ln Time (JIT) and Autonomation have the strongest significance on operational performance while Kaizen, Total Productive Maintenance (TPM) and value stream mapping (VSM) seem to have a lesser, or even negative, effect on it. More recently Garza-Reyes et al. (2018) investigate the effect of the same five essential lean methods on four commonly used indicators for the compliance of environmental performance, i.e., material use, energy consumption, non-product output, and pollutant releases.

Regarding the implementation of the lean tools based on the companies' dimension, the large amount of research was focused on large scale organizations. More recently, the research on lean concepts applications in Small, Medium Enterprises (SME) is increasing (Alkhoraif et al., 2018).

There are many lean methods and tools that can be used to improve the organization's performance. JIT is playing a significant role to achieve a high service level at a minimum cost. As mentioned, the TPM and Kaizen/continuous improvement methods also have a huge impact on the organization's performance. The 5S, for example, is a simple tool which develops discipline and cleanliness at the workplace, maximizing efficiency and productivity (Veres et al., 2018).

In previous work, Silva et al. (2019) evaluates the level of implementation of lean tools in different types and dimension companies, based on an online survey conducted with a set of companies from the North of Portugal. The results showed, in general, the 5S and TPM methods are the ones that have higher progress of implementation, and the kanban tool has a lower level of implementation. It is also possible to conclude that micro and small companies have the lowest levels of implementation of lean procedures.

Based on the mentioned above, and particularly, the work developed by Jabbour et al. (2013), in this study, the lean tools which the impact will be analyzed were the Engagement of workers, the Continuous improvement, the 5S (Sort/Set in order/Shine/Standardize/Sustain), the Total productive maintenance (TPM), the Kanban (pull system), the Just in Time (JIT), the Stock reduction, the Kaizen Circle (discussion groups to improve processes) and the Collaboration with suppliers.

\subsection{Contribution of Green initiatives to environmental performance}

In recent decades, environmental assessment has become commonplace in planning and evaluation at all levels in different organizations. In manufacturing process industries increasing attention has been paid to the environmental impacts of their processes and resulting products.

At the forefront, as a pioneer with the scope of sustainability the well-known Brundtland Commission Report (United Nations World Commission on Environment and Development, 1987) defines sustainable development as the capacity of the current generations to meet their needs without compromising the capacity of achieving the same by the future.

Sustainability issues are mostly integrated into different functions of companies which already perceived these concerns as important aspects for their performance (Alves et al., 2018). In the last few years, sustainability awareness has been introduced as a forefront subject for companies worldwide; it has been supporting companies towards addressing economic, social and environmental goals for society, additionally adopting common practices for the elaboration of sustainable practices (Ching et al., 2014).

The relationship between sustainable development and green business growth have gained increasing importance in the literature in the last years. The debate about environmental strategies in industrial activities is growing in both academia and industries. For instance, the work developed by Aldakhil et al. (2018) investigates the main determinants of integrated supply chain management for green business growth for BRICS (Brazil, Russia, India and China) countries, considering some aspects such as economic growth and environmental policies.

Notwithstanding, the development of sustainable practices by companies have not been accomplished in a similar manner by all industrial sector and countries worldwide. In spite of all these concerns, one of the main challenges to sustainable development in the industrial sector remains as how to apply this concept on their activities, contributing positively to environmental, social, and economic aspects.

Alves et al. (2019) analyzed the implementation level of green practices of companies from the North of Portugal. The results showed that for the consulted companies, environmental issues are not properly addressed 
and formalized by those and clearly indicate that small companies face several berries to implement green actions, particularly the ones related to certification.

Based on the literature review, especially in Jabbour et al. (2013) work, the green strategies, that will be analyzed, were the Clear environmental management policy, the Environmental training for all employees, the 3Rs (Reduction, Reuse and Recycling applied in water, electricity and paper), the Development of products with lower environmental impacts, the Development of productive process with lower environmental impacts, the selection of suppliers based on environmental criteria, the Environmental management system - ISO 14001 (Associação Brasileira de Normas Técnicas, 2004) and the Voluntary disclosure of environmental performance information.

\subsection{Lean and Green relationship and its impact on companies' performance}

The environmental paradigm is promoted using different methods and tools that include green operations, green production, green supply chains, reverse logistics, eco-design, green building, sustainable value stream mapping, and life cycle assessment.

The combination of lean and green initiatives has been contributing to seek alternatives to support companies balance efficiency gains and environmental performance in their industrial processes. The lean philosophy also intends to reduce wastes in all the organizations areas, thus the alignment with the environmental paradigm seems normal (Garza-Reyes, 2015).

In the literature, several studies analyzed the relationship and the impact of lean and green initiatives on the performance on organizations and their applications. Wiengarten et al. (2013) present empirical results examining potential synergetic effects between investments in environmental and quality/lean practices within the supply chain and they conclude that synergetic effects between traditional practices such as lean and quality and environmental practices are possible. More specifically, the impact of lean and quality practices on operational supply chain performance can be amplified through environmental practices such as ISO 14001, pollution prevention, recycling of materials and waste reduction.

Dües et al. (2013) explore and evaluate the relationship and links between lean and green supply chain management practices and the results provides evidence suggesting that lean is beneficial for green practices and the implementation of green practices in turn also has a positive influence on existing lean business practices. Recently Campos \& Vazquez-Brust (2016) verified that synergies can emerge spontaneously even when the implementation of green and lean practices is implemented in different areas, with no department or supportive management team to treat them in a joined way.

Also, Yang et al. (2011), developed an empirical research on manufacturing firms to analyze the impact of lean and green initiatives on the organization's performance. The results showed that combination of these initiatives is positively related to the company's performances.

The combination of lean and green have been adopted by companies aiming to manage their relationships with suppliers in a supply chain management context. Initiatives such as Azevedo et al. (2012), proposed a framework to analyze for the influence of green and lean upstream supply chain management practices on the sustainability performance of companies.

The strongest synergic results are found in practices related to suppliers and customers because these supply chain actors act as bridges between the lean and green areas.

The recent work develop by Dieste et al. (2019), a literature review was conducted in order to identify if firms which have applied lean principles and methods have improved their environmental measures; highlight the environmental measures that are positively affected by lean practices adoption; and underline the most important lean practices in relation to impacting environmental performance. They conclude that firms have to pay attention to the environmental wastes produced, taking into consideration not only lean objectives but also ecological targets. It was suggested that lean practices can improve single environmental measures and, there are some practices that enhance some measures more than others. For example, the following measures are those that might be more positively affected by the deployment of lean practices: air emissions, energy use, solid waste, materials use, toxic/hazardous chemicals use and money saved (Dieste et al., 2019).

\subsection{Sustainable logistics}

Logistics plays an important role on leading companies towards sustainability. These activities are directly related to the process of managing goods in the market channel which involves several steps. Nowadays, logistics has become the backbone of the global economy, driving companies and policymakers to increase their concern for the impact of logistics activities in the environment (Liu et al., 2018). 
Activities developed by the logistics sector have both positive and negative impacts on society. As such, the economic and social gains are clearly the positive contributions of these activities for many countries in different regions worldwide. On the other hand, the negative impacts on the environment, such $\mathrm{CO}_{2}$ emissions generated by the transportations of goods is one of the most concerns for the logistics sector.

Yet, the traditional logistics performs their activities mainly focus on costs, time and accuracy. Nonetheless, concerns related to the impact of logistics activities on the environment have grown in the last decades (Wichaisri \& Sopadang, 2014). It has been led this sector to integrate sustainable strategies in order to reduce the impact on the environment, and at the same time, improve their performance.

According to Wichaisri \& Sopadang (2014), a sustainable logistics system can be defined as a resources management process that combines the principles of sustainable development, namely social, environmental and economic concerns and offers the high-quality costumers service, reducing the impact on the environment and community.

From a sustainable perspective, and as discussed in the previous sections, initiatives related to lean and green are positively associated with environmental practices. The adoption of these practices may contribute to both sustainable logistics and to support companies on minimizing or reducing environmental and social impacts.

Based on the literature, within the growing sustainability awareness in the logistics sector, the promotion of initiatives such as lean and green have substantial importance towards sustainable logistics system. The use of quantitative methods could complement the green lean approach and contribute to a better connection for these concepts, contributing then to propose to organization the adoption of combined techniques lean and green management to develop new strategies for key areas of the organization.

\subsection{Quantitative methods for lean and green analysis}

Over the year have been Increasing the number of researchers using quantitative tools to support hypotheses of lean and green synergies. For instance, Varela et al. (2019) studied the influence of two production philosophies - Lean manufacturing and industry 4.0 - in the three main pillars of sustainability - economic, environmental and social. This study was based on a survey that was analysed by the use of SEM. Cherrafi et al. (2018) revealed a synergetic effect between innovation processes, lean and green practices. All these factors could contribute to the improvement of the green supply chain. A practical approach was studied by Sharma et al. (2015), the authors investigated the impact of green initiatives on the economic performance of the firms. Through the use of SEM approach, they could verify that in the sample of retail companies that they inquired, not only achieved substantial cost savings but also enhance sales, market share and exploit new market opportunities.

In this work, SEM approach was also used aiming to capture and analyse the impact of lean measures in the green features, on the overall performance of companies.

\section{Research methods}

\subsection{Methodology}

In order to achieve the objective of this research a review of the literature related to the green and lean initiative was drawn. Then, aiming to understand the level of these practices (lean and green) practices in the North of Portugal, a case study was considered. The sample taken is a convenient one, due to time and budget constraints.

The methodology used in this research was based on the work developed by Norris et al. (2015), where quantitative methods were used a useful and legitimate approach to investigate primary data, which support clear benefits to describe and to explore variables as well constructs of interest.

Figure 1 summarizes the methodological approach adopted for this research which can be summarized in five main stages: the literature review which provided the fundamentals of the research (section 2 of this paper); the companies' selection; the choice for research methodology; the quantitative analysis of the data and the presentation of conclusions and policy implications.

Based on the literature and the context previously presented, the following research hypothesis was formulated:

$\mathrm{H}$ : Lean management practices (LM) has a positive effect on environmental management practices (EM) in companies.

To identify relevant practices of lean and green in companies, a questionnaire based on the model (Jabbour et al., 2013) was designed (see Appendix A). 


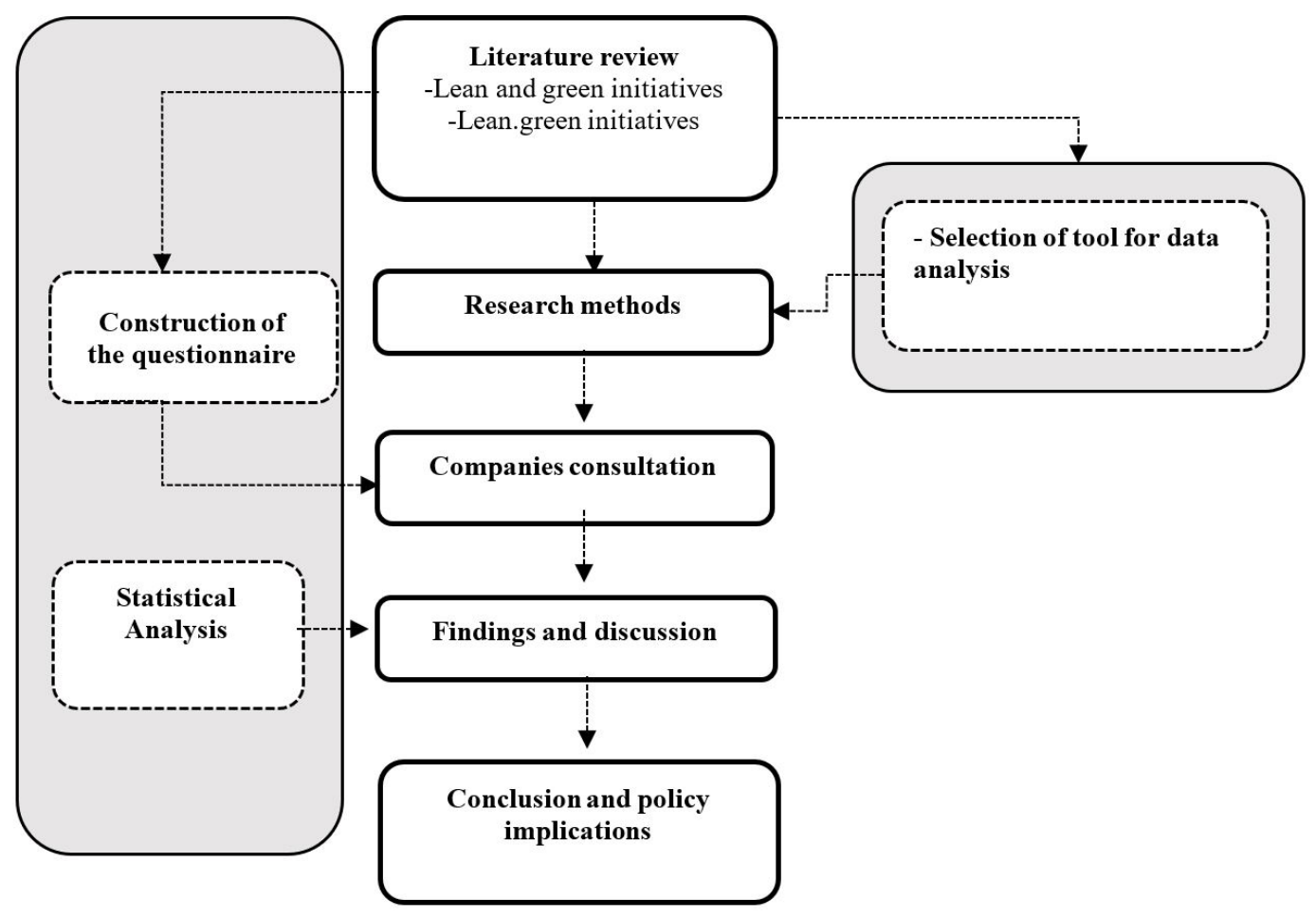

Figure 1. Methodological approach of the research.

\subsection{Measures}

The questionnaire consisted of two parts. The first contains general questions about the characterization of the companies, such as dimension, number of employees related to logistics, and turnover. The second part is the main one, is composed of nine lean attributes and eight questions related to environment practices (see Table 1 for more details). Each company was asked to rate their level of implementation of these practices, using a five-level Likert scale, ranging from 1 (Not implemented) to 5 (Completely implemented).

The model presented in Figure 2 illustrates the relationship between the observed variables and the latent factors.

Table 1. Measures of the level of implementation of lean and green practices.

\begin{tabular}{|c|c|c|}
\hline Latent variable & Observed variable & Description \\
\hline \multirow{9}{*}{ Lean } & LM1 & Engagement of workers \\
\hline & $L M 2$ & Continuous improvement \\
\hline & $L M 3$ & $5 \mathrm{~S}$ (Sort/Set in order/Shine/Standardize/Sustain) \\
\hline & $2 M 4$ & Total productive maintenance (TPM) \\
\hline & LM5 & Kanban (pull system) \\
\hline & $L M 6$ & Just in Time (JIT) \\
\hline & $L M 7$ & Stock reduction \\
\hline & $L M 8$ & Kaizen Circle (discussion groups to improve processes) \\
\hline & LM9 & Collaboration with suppliers \\
\hline \multirow{8}{*}{ Environment } & $E M 1$ & Clear environmental management policy \\
\hline & $E M 2$ & Environmental training for all employees \\
\hline & $E M 3$ & 3Rs (Reduction, Reuse and Recycling applied in water, electricity and paper) \\
\hline & EM4 & Development of products with lower environmental impacts \\
\hline & $E M 5$ & Development of productive process with lower environmental impacts \\
\hline & $E M 6$ & Selection of suppliers based on environmental criteria \\
\hline & $E M 7$ & Environmental management system (1S0 14001 or others) \\
\hline & $E M 8$ & Voluntary disclosure of environmental performance information \\
\hline
\end{tabular}




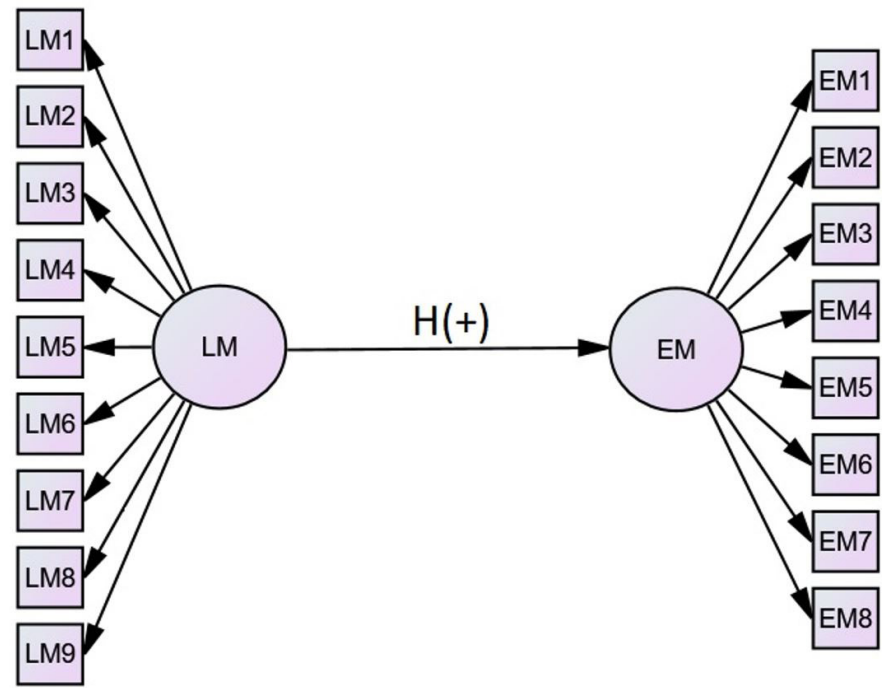

Figure 2. Conceptual model.

\subsection{SEM Approach}

In order to analyse the answers obtained by the survey, a set of tools, under the SEM approach were used. SEM is a confirmatory approach to data analysis requiring the a priori assignment of inter-variable relationships (Wisner, 2003). SEM approach develops in two parts: a measurement model, which considers the relationship between the latent factors and the observed variables in the questionnaire items; and the structural model that represents the path direction and strengths of the relationship between the latent variables (Kline, 2011). There are certain advantages that determine the choice of SEM methodology. First, in contrast to a widely used multiple regression analysis technique, SEM allows the modelling of complex structures including mediating variables.

The covariance-based SEM not only allows incorporation of theoretical constructs as latent variables, but also correlations between different exogenous variables, as well as causal effects and correlations between different endogenous variables. It means that all hypothesized relationships could be tested simultaneously while indirect and direct effects on the endogenous variables could be separated. Additionally, the model fit could be assessed using statistical tests and appropriate goodness-of-fit criteria (Gimenzez et al., 2005). Also, measurement errors could be evaluated separately from other sources of errors which could help to facilitate model validation.

In order to evaluate the fitness of the models, some fit indices are usually calculated. Following Hilton et al. (2004), the Root Mean Square Error of Approximation (RMSEA), the Goodness-of-Fit Index (GFI), the Comparative Fit Index $(\mathrm{CFI})$ and the normed version of the $\chi^{2}$ test statistic $\left(\chi^{2} / d f\right)$, are suitable indices to show the fitness of the model. According to Kline (2011), RMSEA values equal or lower than 0.05 indicate good fit and values lower or equal to 0.1 indicates reasonable fit; for GFI and CFI indices, all normally lie in the range of 0.0 and 1.9, with higher values indicating better fit. The last index, $\chi^{2} / d f$, values in the range of 2.0 and 5.0 are acceptable, with lower values indicating better fit. The statistics tools used were implemented in software SPSS version 24 and AMOS.

\section{Results and discussion}

\subsection{RESULTS}

\subsubsection{Sample}

In this study, a sample of 102 companies which agreed to participate in the questionnaire was analysed. The sample size to support SEM is not always consensual; Nonetheless, Hair et al. (2005) refers that if a SEM model contains at most 5 constructs, each with more than three items (observed variables), with high communalities, can be adequately estimated with samples as small as 100-150. 
The design and the filling of the questionnaire were developed through Google Docs platform. The sample was made up of micro companies (up to 10 employees, 32.4\%), small companies (between 10 and 50 employees, 25.5\%), medium size (between 50 and 250 employees, 16.7\%) and large companies (more than 250 employees, 25.5\%).

\subsubsection{Preliminary analysis}

Table 2 shows the descriptive analysis - N, minimum, maximum, mean, standard deviation, skewness and kurtosis - for each item, as well as the reliability coefficient, calculates ( $\alpha$-Cronbach's alpha) for each dimension of the questionnaire.

Table 2. Descriptive statistics and reliability.

\begin{tabular}{|c|c|c|c|c|c|c|c|c|}
\hline Latent variable & Observed variable & Min & Max & Mean & St. Dev. & $S k$ & Kurt & Alpha \\
\hline \multirow{9}{*}{ Lean } & $L M 1$ & 1 & 5 & 2.49 & 1.481 & 0.262 & -1.528 & \multirow{9}{*}{0.915} \\
\hline & $L M 2$ & 1 & 5 & 3.12 & 1.381 & -0.422 & -1.144 & \\
\hline & $L M 3$ & 1 & 5 & 3.20 & 1.328 & -0.472 & -0.946 & \\
\hline & $L M 4$ & 1 & 5 & 3.42 & 1.238 & -0.822 & -0.244 & \\
\hline & LM5 & 1 & 5 & 2.25 & 1.369 & 0.423 & $-1,477$ & \\
\hline & LM6 & 1 & 5 & 2.65 & 1.426 & -0.001 & -1.558 & \\
\hline & $L M 7$ & 1 & 5 & 3.16 & 1.241 & -0.526 & -0.779 & \\
\hline & $L M 8$ & 1 & 5 & 2.63 & 1.400 & 0.053 & -1.496 & \\
\hline & $2 M 9$ & 1 & 5 & 3.06 & 1.296 & -0.278 & -0.989 & \\
\hline \multirow{8}{*}{ Environment } & EM1 & 1 & 5 & 3.45 & 1.087 & -0.698 & 0.031 & \multirow{8}{*}{0.895} \\
\hline & $E M 2$ & 1 & 5 & 3.28 & 1.146 & -0.540 & -0.393 & \\
\hline & $E M 3$ & 1 & 5 & 3.40 & 1.017 & -0.649 & 0.262 & \\
\hline & EM4 & 1 & 5 & 2.77 & 1.342 & -0.154 & -1.411 & \\
\hline & EM5 & 1 & 5 & 2.78 & 1.302 & -0.193 & -1.265 & \\
\hline & EM6 & 1 & 5 & 2.51 & 1.391 & 0.193 & -1.416 & \\
\hline & $E M 7$ & 1 & 5 & 2.45 & 1.558 & 0.455 & -1.406 & \\
\hline & EM8 & 1 & 5 & 2.61 & 1.415 & 0.236 & -1.330 & \\
\hline
\end{tabular}

Descriptive statistics for each item revealed that the answers to almost items ranged between the minimum and maximum allowed, indicating a reasonable existence of response variety.

With respect to latent variable Lean, practices LM3 and LM4 present the higher means values, meaning more progress of implementation. On the other hand, the lowest means values are related to the procedures LM 5 and LM1, probably due to the $5 \mathrm{~S}$ tool and the TPM method are considered hard lean practices which are more extensively used.

The lowest averages obtained for green practices are related to the environmental management system (EM7) and the selection of suppliers based on environmental criteria (EM6), both practices that carry a huge financial burden for businesses. By another hand, the first three observed variables (EM1, EM2, and EM3), have the highest means; these items are related to more rooted measures in the daily (labour and personal) of the employees. The standard deviation does not present great discrepancies between items. More detailed results about these items can be found in (Silva et al., 2019 and Alves et al., 2019).

A conservative approach was followed in order to obtain variables with approximate normal distribution; skewness and kurtosis values were considered in this decision, following reference values, such as skewness value $<|3|$ and kurtosis $<|8|$, according to Kline (2011).

Concerning the reliability of the scales, through the alpha analysis of Cronbach, the constituent items of the dimensions represent values greater than 0.7 , which performs good internal reliability of the questionnaire.

\subsubsection{Factor analysis}

In order to determine how well the questionnaire observed variables were able to explain the relevant attributes (latent variables), confirmatory factor analysis was conducted. Principal Component Analysis (PCA) is a factorial model in which factors are based on total variance.

For this analysis, it is necessary to evaluate the Kaiser-Meyer-Olkin (KMO) sampling adequacy measure and the Bartlett sphericity test. Both indicate the adequacy of the data for the accomplishment of the factorial analysis (Kline, 2011).

Table 3 shows the results. For all items, the achieved factor loadings were greater than 0.5 , implying that represent their relevant attributes. Through the results of the factorial weights in both dimensions, is possible 


\begin{tabular}{|c|c|c|c|c|c|}
\hline Latent variable & Observed variable & Communalities & Loadings & KMO Measure & Bartlett's test \\
\hline \multirow{9}{*}{ Lean } & $L M 1$ & 0.632 & 0.795 & \multirow{9}{*}{0.857} & \multirow{9}{*}{0.000} \\
\hline & $L M 2$ & 0.639 & 0.799 & & \\
\hline & $L M 3$ & 0.694 & 0.833 & & \\
\hline & LM4 & 0.633 & 0.796 & & \\
\hline & LM5 & 0.558 & 0.747 & & \\
\hline & LM6 & 0.572 & 0.756 & & \\
\hline & $L M 7$ & 0.592 & 0.770 & & \\
\hline & $L M 8$ & 0.615 & 0.784 & & \\
\hline & $L M 9$ & 0.448 & 0.669 & & \\
\hline \multirow{8}{*}{ Environment } & $E M 1$ & 0.577 & 0.760 & \multirow{8}{*}{0.855} & \multirow{8}{*}{0.000} \\
\hline & $E M 2$ & 0.682 & 0.826 & & \\
\hline & $E M 3$ & 0.632 & 0.795 & & \\
\hline & $E M 4$ & 0.607 & 0.779 & & \\
\hline & EM5 & 0.707 & 0.841 & & \\
\hline & EM6 & 0.603 & 0.776 & & \\
\hline & $E M 7$ & 0.413 & 0.643 & & \\
\hline & $E M 8$ & 0.546 & 0.739 & & \\
\hline
\end{tabular}

to conclude that all the items present a positive correlation with the latent variables. Regarding the suitability measure of the KMO sample, the result obtained of 0.857 and 0.855 are close to 1 , indicating an average degree of adequacy of the Principal component analysis. In both cases, the calculated chi-squared statistic was significant at the level of $0.000(<0.05)$, indicating the presence of correlation between the various items.

Regarding the communalities (after extraction), the analysis showed that the lowest values were LM9 and EM, for this dimension these variables were lower than the recommended by Field (2005). It calls attention to the fact of not traducing the best behaviour of the total variance, it could be an indicator to be alert in the SEM approach, particularly in measurement models.

In the next, the first step of the SEM approach is presented, namely the measurement of the model, where both latent variables were estimated.

\subsubsection{Measurement model}

The first measurement model tested was related to lean practices. This model was evaluated resorting to 9 items shown in Table 1. Two of the items exhibited either large errors variances or insignificant parameter estimates, thus we decided to delete since the minimum number of items required is the same reached. Figure 3 shows the lean measurement model. The analysis of the modification indices suggested that LM4 and LM6 influenced each other.

For the Environment practices measurement model was tested. The eight items from Table 1 were used to evaluate the model. The item EM7 shown lowest results and it was dropped from the model (see Figure 4).

The analysis of the modification indices considered that issues such as evaluation of the theoretical plausibility of the modifications and the errors of measurement are correlated (e11<->e12 and e14 <->e15). It led to the considerable improvement of the adjusted model. This way, all indices reach good fit, indicated that the latent variable is a good estimative through these items.

\subsubsection{Structural model}

The structural model was analysed based on the modified measurement models, using the maximum likelihood estimation method. Figure 5 shows the structural model, the standardized coefficients and fit indices for evaluation. The estimation of structural parameters is similar to the estimation of correlations in the measurement models.

The data supported hypothesis $\mathrm{H}$ presented previously, corroborating to the hypothesis that lean practices have a positive effect on Environment practices $(\beta=0.87 ; p \leq 0.001)$. All coefficients are significant at 0.05 level, and the model indices indicates that fit the data sample well. All items have high factor loadings and the percentage of the variance of environmental practices explained by the model is $76 \%$. 


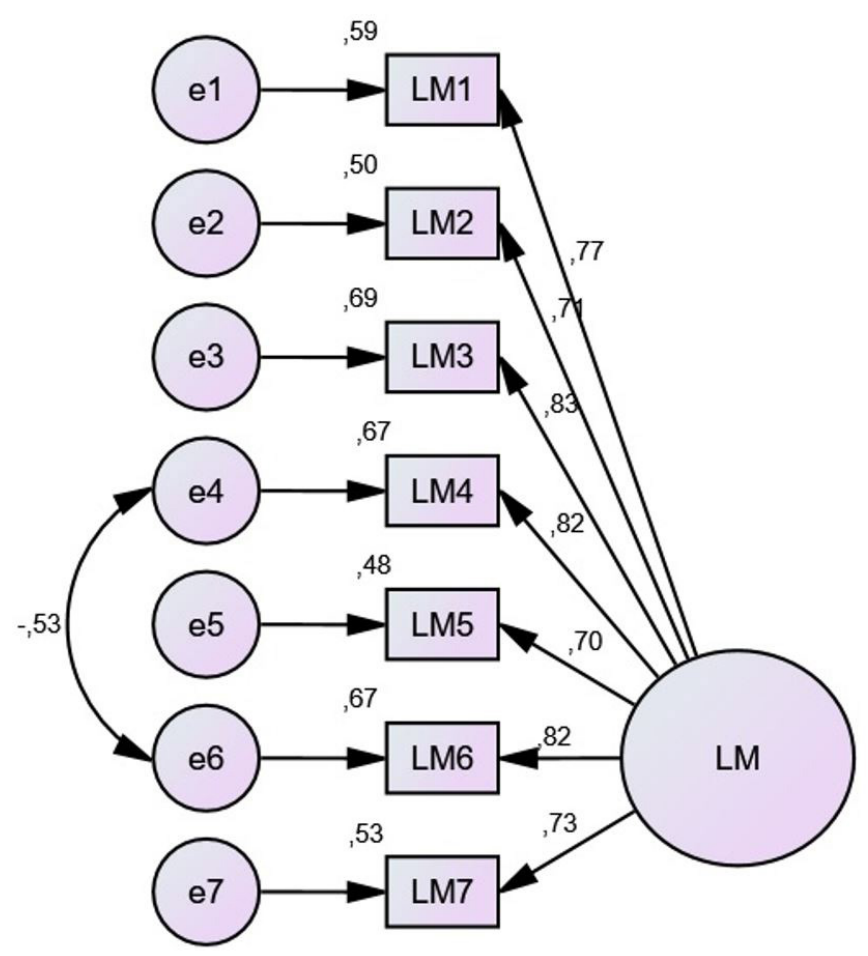

Figure 3. Standardized coefficients and covariance of lean practices measurement. (Model Fit Indices: RMSEA $=0.087 ; \mathrm{GFl}=0.946 ; \mathrm{CFl}=0.975 ; \chi^{2} / d f=1.772$ ).

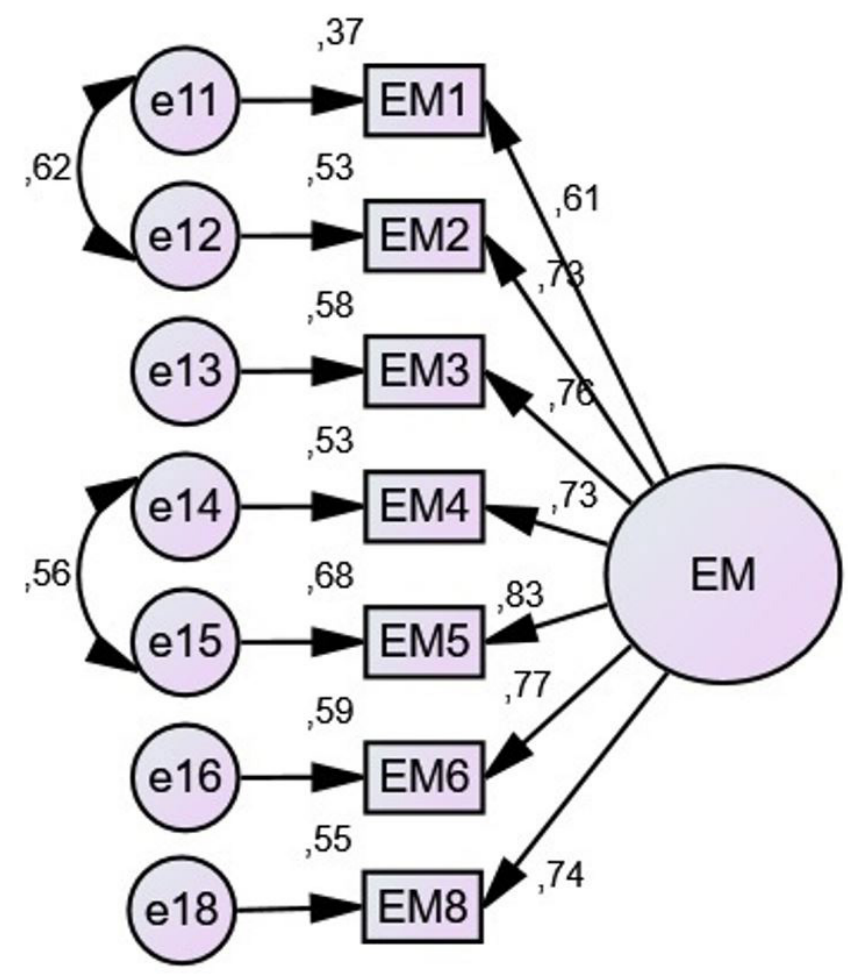

Figure 4. Standardized coefficients and covariance of environment practices measurement.

(Model Fit Indices: RMSEA $=0.098 ; \mathrm{GFl}=0.942 ; \mathrm{CFl}=0.974 ; \chi^{2} / d f=1.976$ ). 


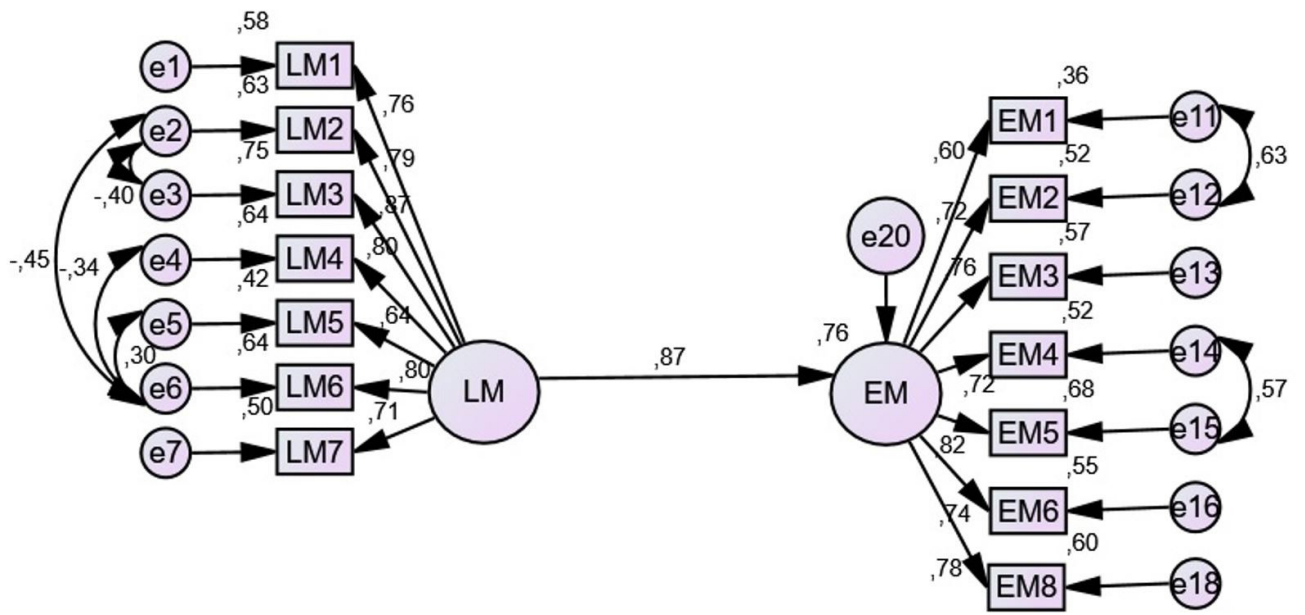

Figure 5. Structural model for lean and green practices.

(Model Fit Indices: RMSEA $=0.100 ; \mathrm{GFl}=0.855 ; \mathrm{CFl}=0.715 ; \chi^{2} / d f=2.002$ ).

\subsection{Discussion}

\subsubsection{Level of implementation of lean and green by Portuguese's companies}

This research has investigated the level of implementation of lean and green practices of a set of companies located in the North of Portugal. The results showed that show from the consulted companies, the levels of implementation of lean procedures, are in ongoing progress. The implementation of some integrated lean production systems requires specific knowledge and money spent.

For the green perspective, the results showed that the level of implementation of these initiatives is at the same level of the lean practices. This fact could be associated with two important aspects: the lack of awareness about the benefits of implementing these practices and also the lack of financial support to allow companies to be connected with green procedures.

Despite being an initial analysis, the results showed that for the consulted companies, lean and green initiatives are not properly addressed and formalized by those.

\subsubsection{The effect of the lean and green combination on companies' performance}

This research has investigated the possibility of combining lean and green initiatives in an industrial context. These two initiatives have contributed to minimize waste and at the same time minimize the environmental impacts of the companies. Although the potential of lean and green for economic and environmental gains, few companies have been focusing on the combination of these methodologies.

The environmental impact of logistics has been the target of several types of research. Given the urgent need for sustainability, reduce the negative impact of logistics on the environment and society is also a new priority for logistics managers.

The research showed that lean and green has also a positive impact on the logistics processes of companies. For instance, reverse logistics which is considered as a green initiative has been attracted the attention of companies over the past years. Also, lean initiatives have been supporting companies on waste reduction as well as improving efficiency through the use of different tools.

The statistical analysis showed that lean environmental practices and green practices are positively associated.

\subsubsection{Main barriers faced by companies}

Lean and green initiatives have been important instruments in twofold: to support companies on improving their activities and to support them to overcome their major challenge, namely achieve sustainability.

The main barriers faced by the consulted companies of this research are related to three key aspects, lack of information about the benefits of lean and green initiatives, lack of technology and lack of environmental practices. 
The results indicate that in the long term, to overcome these barriers an important first step for the companies would be to get support to implement lean and green initiatives. The investment in lean and green initiatives could facilitate a better understanding of the importance of using these tools towards sustainable development of the companies.

\section{Conclusions and future work}

Initiatives connecting lean and green have been supporting companies on developing methodologies which may benefit both company and the environment. For instance, while lean tools focus on operational efficiency of companies, green tools focus on environmental issues. This combination contributes to sustainability issues, demonstrating that lean and green have synergistic effect on improving operational efficiency and environmental performance into organizations.

In this sense, this research brings some contributions to both academy and companies. Firstly, further discussion about the benefits of combining lean and green towards sustainability. Secondly, the development of a structural model for lean and green practices was presented, this model contributes to a better understanding of these practices, which can also lead companies to develop strategic initiatives towards sustainability.

Another implication pictured from this work is that despite the potential impact of lean and green initiatives to economic aspects into their operations as well developing actions to minimize its impacts, for the selected sample few companies have been used these initiatives.

Regardless of these potential contributions, it becomes evident that the positive impacts of the aforementioned initiatives may contribute to companies to overcome the challenge of sustainability.

Despite the contribution of this paper, some limitations should be noted namely, the convenience of the sample, related to the sample dimension and characterization of the companies.

As future work, the authors suggest the study of new variables they could analyse the impact of the supply chain performance, such as supplier management strategy and costumer relationship strategy.

\section{Acknowledgements}

This research was supported by the FCT - Fundação para a Ciência e Tecnologia, through the following projects CAPES and Science Without Borders scholarship, BEX Process 10.190-13-9 (Alves); UID/EMS/04005/2019 (Silva); and UID/MAT/04106/2019 (Rodrigues).

\section{References}

Aldakhil, A. M., Nassani, A. A., Awan, U., Abro, M. M. Q., \& Zaman, K. (2018). Determinants of green logistics in BRICS countries: An integrated supply chain model for green business. Journal of Cleaner Production, 195, 861-868. http://dx.doi.org/10.1016/j. jclepro.2018.05.248.

Alkhoraif, A., Rashid, H., \& McLaughlin, P. (2018). Lean implementation in small and medium enterprises: Literature review. Operations Research Perspectives, 6, 100089. https://doi.org/10.1016/j.orp.2018.100089

Almanei, M., Salonitis, K., \& Xu, Y. (2017). Lean implementation frameworks: the challenges for SMEs. Procedia CIRP, 63, $750-755$. http://dx.doi.org/10.1016/j.procir.2017.03.170.

Alves, W., Ferreira, P., \& Araújo, M. (2018). Sustainability awareness in Brazilian mining corporations: The case of Paraíba state. Environment, Development and Sustainability, 20(S1), 41-63. http://dx.doi.org/10.1007/s10668-018-0171-6.

Alves, W., Silva, Â., \& Rodrigues, H. S. (2019, September 25-27). Sustainable practices: An optimization analysis of ressources in portuguese companies. In 15th International Symposium on Operations Research. Bled, Slovenia.

Associação Brasileira de Normas Técnicas (2004), NBR ISO 14001 - Sistema de gestão ambiental: Especificação e diretrizes para uso. Rio de Janeiro: ABNT. 14 p.

Azevedo, S. G., Carvalho, H., Duarte, S., \& Cruz-Machado, V. (2012). Influence of green and lean upstream supply chain management practices on business sustainability. IEEE Transactions on Engineering Management, 59(4), 753-765. http://dx.doi.org/10.1109/ TEM.2012.2189108.

Bahr, W., \& Sweeney, E. (2019). Environmental sustainability in the follow-up and evaluation stage of logistics services purchasing: Perspectives from UK Shippers and 3PLs. Sustainability, 11(9), 2460. http://dx.doi.org/10.3390/su11092460.

Belekoukias, l., Garza-Reyes, J. A., \& Kumar, V. (2014). The impact of lean methods and tools on the operational performance of manufacturing organisations. International Journal of Production Research, 52(18), 5346-5366. http://dx.doi.org/10.1080/00207 543.2014.903348.

Campos, L. M. S., \& Vazquez-Brust, D. A. (2016). Lean and green synergies in supply chain management. Supply Chain Management, 21(5), 627-641. http://dx.doi.org/10.1108/SCM-03-2016-0101. 
Cherrafi, A., Garza-Reyes, J. A., Kumar, V., Mishra, N., Ghobadian, A., \& Elfezazi, S. (2018). Lean, green practices and process innovation: A model for green supply chain performance. International Journal of Production Economics, 206, 79-92. http://dx.doi.org/10.1016/j. ijpe.2018.09.031.

Choudhary, S., Nayak, R., Dora, M., Mishra, N., \& Ghadge, A. (2019). An integrated lean and green approach for improving sustainability performance: a case study of a packaging manufacturing SME in the U.K. Production Planning and Control, 30(5-6), 353-368. http://dx.doi.org/10.1080/09537287.2018.1501811.

Ching, H. Y., Gerab, F., \& Toste, T. H. (2014). Scoring Sustainability Reports using GRI indicators: A Study based on ISE and FTSE4Good Price Indexes. Journal of Management Research, 6(3), 27. http://dx.doi.org/10.5296/jmr.v6i3.5333.

Dey, A., LaGuardia, P., \& Srinivasan, M. (2011). Building sustainability in logistics operations: a research agenda. Management Research Review, 34(11), 1237-1259. http://dx.doi.org/10.1108/01409171111178774.

Dieste, M., Panizzolo, R., Garza-Reyes, J. A., \& Anosike, A. (2019). The relationship between lean and environmental performance: Practices and measures. Journal of Cleaner Production, 224, 120-131. http://dx.doi.org/10.1016/j.jclepro.2019.03.243.

Dües, C. M., Tan, K. H., \& Lim, M. (2013). Green as the new Lean: How to use Lean practices as a catalyst to greening your supply chain. Journal of Cleaner Production, 40, 93-100. http://dx.doi.org/10.1016/j.jclepro.2011.12.023.

Field, A. (2005). Discovering statistics using SPSS (2nd ed.). London: Sage Publications Ltd.

Garza-Reyes, J. A. (2015). Lean and green-a systematic review of the state of the art literature. Journal of Cleaner Production, 102, 18-29. http://dx.doi.org/10.1016/j.jclepro.2015.04.064.

Garza-Reyes, J. A., Kumar, V., Chaikittisilp, S., \& Tan, K. H. (2018). The effect of lean methods and tools on the environmental performance of manufacturing organisations. International Journal of Production Economics, 200, 170-180. http://dx.doi. org/10.1016/j.jpe.2018.03.030.

Gimenzez, C., Large, R., \& Ventura, E. (2005). SCM Research Methodologies: Employing structural equation modeling. In H. Kotzab, S. Seuring, M. Müller \& G. Reiner (Eds.), Research methodologies in supply chain management. Heidelberg: Physica-Verlag. https:// doi.org/978-3-7908-1636-5.

Hair, J. F., Black, Bi., Babin, B., Anderson, R., \& Tatham, R. L. (2005). Multivariate data analysis (6th ed.). Upper Saddle River, NJ: Prentice Hall.

Hilton, S. C., Schau, C., \& Olsen, J. A. (2004). Survey of attitudes toward statistics: Factor structure invariance by gender and by administration time. Structural Equation Modeling, 11(1), 92-109. http://dx.doi.org/10.1207/S15328007SEM1101_7.

Jabbour, A. B. L. S., Jabbour, C. J. C., Freitas, W. R. S., \& Teixeira, A. A. (2013). Lean and green?: evidências empíricas do setor automotivo brasileiro. Gestão \& Produção, 20(3), 653-665. http://dx.doi.org/10.1590/S0104-530X2013000300011.

Kline, R. B. (2011). Principles and practice of structural equation modeling. New York: Guilford Press.

Liu, J., Yuan, C., Hafeez, M., \& Yuan, Q. (2018). The relationship between environment and logistics performance: Evidence from Asian countries. Journal of Cleaner Production, 204, 282-291. http://dx.doi.org/10.1016/j.jclepro.2018.08.310.

Norris, J. M., Plonsky, L., Ross, S. J., \& Schoonen, R. (2015). Guidelines for reporting quantitative methods and results in primary research. Language Learning, 65(2), 470-476. http://dx.doi.org/10.1111/lang.12104.

Organisation for Economic Co-operation and Development (2010). Guidance on Sustainability Impact Assessment. Paris: OECD Publishing.

Pearce, A., Pons, D., \& Neitzert, T. (2018). Implementing lean-Outcomes from SME case studies. Operations Research Perspectives, 5, 94-104. http://dx.doi.org/10.1016/j.orp.2018.02.002.

Rashidi, K., \& Cullinane, K. (2019). Evaluating the sustainability of national logistics performance using Data Envelopment Analysis. Transport Policy, 74, 35-46. https://doi.org/10.1016/j.tranpol.2018.11.014

Sharma, A., Rajan, A., Jose, R., \& Rao, P. (2015). Applying structural equation modeling for green supply chain in retail domain. International Journal of Business Analytics and Intelligence, 3(2), 55-64. http://dx.doi.org/10.21863/ijbai/2015.3.2.006.

Silva, Â., Alves, W., \& Rodrigues, H. S. (2019, September 25-27). Level of Implementation of Lean Manufacturing Tools: A Case Study in the North of Portugal. In 15th International Symposium on Operations Research. Bled, Slovenia.

United Nations World Commission on Environment and Development. (1987). Our Common Future: Report of the world commission on environment and development. Oxford: Oxford University Press.

Varela, L., Araújo, A., Ávila, P., Castro, H., \& Putnik, G. (2019). Evaluation of the relation between lean manufacturing, industry 4.0, and sustainability. Sustainability, 11(5), 1-19. http://dx.doi.org/10.3390/su11051439.

Veres, C., Marian, L., Moica, S., \& Al-Akel, K. (2018). Case study concerning 5 S method impact in an automotive company. Procedia Manufacturing, 22, 900-905. https://doi.org/10.1016/j.promfg.2018.03.127

Wichaisri, S., \& Sopadang, A. (2014, December 10-13). Sustainable logistics system: A framework and case study. In IEEE International Conference on Industrial Engineering and Engineering Management (pp. 1017-1021). Bangkok, Thailand: IEEE. https://doi. org/10.1109/IEEM.2013.6962564

Wiengarten, F., Fynes, B., \& Onofrei, G. (2013). Exploring synergetic effects between investments in environmental and quality/lean practices in supply chains. Supply Chain Management, 18(2), 148-160. http://dx.doi.org/10.1108/13598541311318791.

Wisner, J. D. (2003). A structural equation model of supply chain management strategies and firm performance. Journal of Business Logistics, 24(1), 1-26. http://dx.doi.org/10.1002/j.2158-1592.2003.tb00030.x.

Yang, M. G., Hong, P., \& Modi, S. B. (2011). Impact of lean manufacturing and environmental management on business performance: An empirical study of manufacturing firms. International Journal of Production Economics, 129(2), 251-261. http://dx.doi. org/10.1016/j.jpe.2010.10.017. 
APPENDIX A - Questionnaire.

Please select the most suitable answer, regarding your company.

Part 1 - Characterization of the company

1) Dimension of the company

$\square$ Micro

$\square$ Small

$\square$ Medium

$\square$ Large

2) Number of employees associated with logistics

$\square[0 ; 3[$

$\square[3 ; 6[$

$\square[6 ; 9[$

$\square[12 ; 15[$

$\square 15$ or more

3) Turnover (in euros)

$\square[0 ; 100 \mathrm{k}[$

口 [100k; 250k[

$\square[250 \mathrm{k} ; 500 \mathrm{k}[$

$\square[500 \mathrm{k} ; 1 \mathrm{M}[$

$\square[1 \mathrm{M} ; 5 \mathrm{M}[$

$\square 5 \mathrm{M}$ or more

Part 11 - Implementation Level of Lean and Green measures in the company

\begin{tabular}{|c|c|c|c|c|c|}
\hline Description & $\begin{array}{c}\text { Not } \\
\text { implemented }\end{array}$ & $\begin{array}{l}\text { Starting to } \\
\text { implement }\end{array}$ & $\begin{array}{c}\text { Partially } \\
\text { implemented }\end{array}$ & $\begin{array}{l}\text { Considerably } \\
\text { implemented }\end{array}$ & $\begin{array}{l}\text { Completely } \\
\text { implemented }\end{array}$ \\
\hline Engagement of workers & $\square$ & $\square$ & $\square$ & $\square$ & $\square$ \\
\hline Continuous improvement & $\square$ & $\square$ & $\square$ & $\square$ & $\square$ \\
\hline $5 \mathrm{~S}$ (Sort/Set in order/Shine/Standardize/Sustain) & $\square$ & $\square$ & $\square$ & $\square$ & $\square$ \\
\hline Total productive maintenance (TPM) & $\square$ & $\square$ & $\square$ & $\square$ & $\square$ \\
\hline Kanban (pull system) & $\square$ & $\square$ & $\square$ & $\square$ & $\square$ \\
\hline Just in Time (JIT) & $\square$ & $\square$ & $\square$ & $\square$ & $\square$ \\
\hline Stock reduction & $\square$ & $\square$ & $\square$ & $\square$ & $\square$ \\
\hline Kaizen Circle (discussion groups to improve processes) & $\square$ & $\square$ & $\square$ & $\square$ & $\square$ \\
\hline Collaboration with suppliers & $\square$ & $\square$ & $\square$ & $\square$ & $\square$ \\
\hline Clear environmental management policy & $\square$ & $\square$ & $\square$ & $\square$ & $\square$ \\
\hline Environmental training for all employees & $\square$ & $\square$ & $\square$ & $\square$ & $\square$ \\
\hline $\begin{array}{l}\text { 3Rs (Reduction, Reuse and Recycling applied in water, electricity } \\
\text { and paper) }\end{array}$ & $\square$ & $\square$ & $\square$ & $\square$ & $\square$ \\
\hline Development of products with lower environmental impacts & $\square$ & $\square$ & $\square$ & $\square$ & $\square$ \\
\hline $\begin{array}{l}\text { Development of productive process with lower environmental } \\
\text { impacts }\end{array}$ & $\square$ & $\square$ & $\square$ & $\square$ & $\square$ \\
\hline Selection of suppliers based on environmental criteria & $\square$ & $\square$ & $\square$ & $\square$ & $\square$ \\
\hline Environmental management system (1S0 14001 or others) & $\square$ & 口 & $\square$ & $\square$ & $\square$ \\
\hline Voluntary disclosure of environmental performance information & $\square$ & $\square$ & $\square$ & $\square$ & $\square$ \\
\hline
\end{tabular}

